\title{
The Guinardera quarry (Sant Martí de Tous, Barcelona): A new chert exploitation location during historical times
}

Bruno Gómez de Soler ${ }^{1,2}$, Miguel Soares-Remiseiro ${ }^{1,2}$, Andion ArteagaBrieba $^{2,1}$, Gisela Borràs ${ }^{3}$, Javier Cámara ${ }^{3}$, Gerard Campeny ${ }^{1,2}$, M. Gema Chacón ${ }^{1,2,4}$, Juan Luis Fernández-Marchena ${ }^{5}$, Vicenç Guinart ${ }^{6}$, Gerard López ${ }^{7,2}$, Bàrbara Mas ${ }^{1,5}$, María Soto ${ }^{8,9}$, Alfredo Suesta ${ }^{1,2}$, Kateryna Shkarinska ${ }^{10}$, Iván Ramírez-Pedraza ${ }^{1,2}$, Cristina Val-Peón ${ }^{11}$, Josep Vallverdú ${ }^{1,2}$

1. Institut Català de Paleoecologia Humana i Evolució Social (IPHES-CERCA), Zona Educacional 4, Campus Sescelades URV (Edifici W3), 43007 Tarragona, Spain. Email: Gómez de Soler: bgomez@iphes.cat; Soares-

Remiseiro: masoares@iphes.cat; Campeny: gcampeny@iphes.cat; Chacón: gchacon@iphes.cat;

Suesta: asuesta@iphes.cat; Ramírez-Pedraza: iramirez@iphes.cat; Vallverdú: jvallverdu@iphes.cat

2. Universitat Rovira i Virgili (URV), Departament d'Història i Història de l'Art, Avinguda de Catalunya 35, 43002 Tarragona, Spain. Email: Arteaga-Brieba: andionarteaga@gmail.com

3. Universitat Autònoma de Barcelona (UAB), Dept. de Prehistòria, Edifici B, Facultat de Filosofia i Lletres, 08193 Bellaterra (Barcelona), Spain. Email: Borràs: gborrasferrer@gmail.com; Cámara: javi.camara.manzaneda@gmail.com

4. UMR7194 - HNHP (CNRS - MNHN -UPVD - Sorbonne Universités), Palais de Chaillot. Musée de l'Homme, 17 Place du Trocadéro, 75016 Paris, France.

5. SERP, Seminari d'Estudis i Recerques Prehistòriques. Secció Prehistòria i Arqueologia, Facultat de Geografia i Història, Universitat de Barcelona, C/Montalegre 6-8, 08001 Barcelona, Spain. Email: Fernández-Marchena: juanl.ferna@gmail.com; Mas: barbara.mas86@gmail.com

6. Independent researcher. Spain. Email: Guinart: calvicensdetous@gmail.com

7. Universitat Oberta de Catalunya (UOC), Avenida Tibidabo, 39-43, 08035 Barcelona, Spain. Email: López: g_lp04@hotmail.com

8. Madrid Institute for Advanced Study (MIAS). Casa Velázquez. Ciudad Universitaria C/de Paul Guinard, 3 28040, Madrid, Spain - Universidad Autónoma de Madrid. C/ Einstein 13 Pabellón C 1ª Planta, 28049, Madrid, Spain. Email: Soto: sotoquesadamaria@gmail.com

9. Universidad Autónoma de Madrid. Departamento de Prehistoria y Arqueología. Facultad de Filosofía y Letras. Ciudad Universitaria de Cantoblanco, 28049, Madrid, Spain.

10. Univeristat de Girona (UdG), Dept. d’Història i Història de l’Art, Pl. Ferrater Mora, 1, 17004, Girona, Spain. Email: Shkarinska: ailrkim@hotmail.com

11. Institute of Neotectonics and Natural Hazards, RWTH Aachen University, Lochnerstrasse 4-20, 52056 Aachen, Germany. Email: Val-Peón: cvpwol@gmail.com

\begin{abstract}
:
In 2014, an anthropic accumulation of chert material was discovered in La Guinardera area, at the southwest of the Sant Martí de Tous town (Barcelona, NE Iberian Peninsula). In 2018 a first archaeological intervention was carried out in two locations: La Guinardera and La Guinardera Nord. After the fieldworks, these two accumulations were interpreted as chert workshops. These workshops are in the St. Genís Formation, included within La Noguera lacustrine system and dated to the
\end{abstract}

Published by the School of History, Classics and Archaeology, University of Edinburgh ISSN: 2055-0472. URL: http://journals.ed.ac.uk/lithicstudies/

Except where otherwise noted, this work is licensed under a CC BY 4.0 licence. 
Priabonian age (upper Eocene). The St. Martí de Tous area presents shallow lacustrine conditions typical of sabkha environments, in which layers of gypsums and sandy lutites are interspersed with tabular red sandstone levels, yielding different varieties of chert.

The Guinardera chert is characterized by a fairly homogeneous matrix, presenting a fine texture, with a microcrystalline and spherulitic length-slow chalcedony matrix, and a combination of grey colours, in general of dark hues, with an opaque diaphaneity but translucent at the edges.

The archaeological assemblage from La Guinardera Nord site allows us to identify a chert workshop for the production of gunflints. The heterogeneity of the assemblage at La Guinardera site precludes assigning it to any single chrono-cultural period or function.

The technological characterization of La Guinardera Nord site reveals distinctive attributes of a gunflint workshop that can be differentiated from prehistoric workshops. The presence of square and thick preforms, oxide traces on butts and ventral faces, marked bulbs and thick platforms, together with fresh edges on flakes and blades and the near-absence of patinated materials, corroborate it.

The presence of these two deposits within the above-mentioned formation shows us a repeated landscape exploitation pattern for raw material extraction, since references chert use range from the Middle Palaeolithic (e.g., Abric Romaní) to historical times (e.g., La Guinardera Nord).

Keywords: Sant Martí de Tous; chert; quarry; La Guinardera; gunflint preforms

\section{Introduction}

Lithics represent some of the most important archaeological evidence for demarcating an exploited territory. From prehistory to modern times, lithics, and more specifically flint and chert, have been exploited and used for different purposes in western Europe. Not only in prehistoric times was chert a raw material of great value for producing lithic tools. In modern times too, as Emy (1978) rightly pointed out, its exploitation for military and civil (gunflints), agricultural (threshing inserts) and domestic (lighters fire-flints) purposes was of great importance, with the onset of the so-called "second golden age of flint".

This article presents two new archaeological sites discovered on the eastern margin of the Ebro Basin (NE Iberian Peninsula) notable for the extraction of chert as a raw material: $\mathrm{La}$ Guinardera (LG), of uncertain chronological attribution due to its exploitation through multiple periods; and La Guinardera Nord (LGN), a location used for the exploitation of chert for gunflints in modern times. Due to the heterogeneity of the assemblage and the difficulties associated with the chronological attribution of La Guinardera site (which comprises an admixture of material from different periods without being in stratigraphic position), this work will focus on the homogeneous assemblage of La Guinardera Nord. The presence of chert outcrops and extraction quarries within a concentrated area makes it possible to study the evolution of territorial exploitation practices from Palaeolithic huntergatherers (e.g., Abric Romaní) (Gómez de Soler 2016: Chapter 7, 8 \& 9; Gómez de Soler et al. 2019; 2020a; 2020b), through the Neolithic period (e.g., Vilars de Tous) (Cámara 2017; Clop 2005), to modern times.

The archaeological intervention in the La Guinardera Quarry (Sant Martí de Tous, Anoia, Barcelona) was undertaken with the aim of recognizing the exploitation of chert through history. In recent years, through the research project carried out by the IPHES Research Institute at Abric Romaní, a program of geo-archaeological surveys and petrographic characterization of chert has been carried out with the aim of determining the geographical provenance of the lithic materials (Gómez de Soler 2016: Chapter 7; Gómez de Soler et al. 2019; 2020a). These works have revealed multiple chert locations and identified a number of quarries, one of them being La Guinardera Quarry, which can be divided into two chert workshops: La Guinardera (LG) and La Guinardera Nord (LGN). 
Even though the project focused on searching for prehistoric workshops, the LGN deposit has revealed a surface gunflint workshop associated with a primary chert location. In the Iberian Peninsula, this type of deposit has historically presented problems of chronocultural affiliation, due to the absence of other materials (e.g., fauna, ceramics, charcoal), in surface contexts in general, as well as to their inherent nature as a workshop, with a lack of final products and with abandoned preforms that are difficult to identify leading to erroneous prehistoric chronological attributions (Barandiarán 1974; Merino 1965; Morgado \& Roncal 2009: 16; Roncal et al. 1996), that can only be corrected with radiocarbon dating when datable material is available. In this context, a preliminary study of the materials from LGN presents an opportunity to delve into the characteristics of these workshops dedicated in modern times to the production of gunflints and other tools (threshing stones inserts or lighters fire-flints), contributing new data to shed light on these activities.

The beginnings of the gunflint industry is related to a new ignition system: the wheel lock (Borja Pérez 1997). There are reports of the use of gunflint in the early $16^{\text {th }}$ century, been developed in the Netherlands in the second half of this century, and it was already widely documented by the $17^{\text {th }}$ century (Barandiarán 1974). However, it was in the $18^{\text {th }}$ century with technical improvements in firearms that its production took off throughout Europe, due to its adoption by armies and the consequent increase in demand accompanied by a specialized tradecraft of "flintknappers". At the end of the $19^{\text {th }}$ century, with the introduction of percussion caps using fulminate cartridges, its use in weapons entered into decline. It was thus in the $18^{\text {th }}$ century and the first two thirds of the $19^{\text {th }}$ century that this trade had its highest levels of production (Morgado \& Roncal 2009: 79; Sopena Garreta 1978: 13).

In a nutshell, the history of firearms can be explained through the advances in their ignition system (Barandiarián 1974; Rodríguez Hernández 2016). The first system appeared in the last quarter of the $15^{\text {th }}$ century in Germany and was based on the ignition of the gunpowder by the application of a slow-burning match; this was called matchlock (Borja Pérez 1997). Later, the first quarter of the $16^{\text {th }}$ century saw the invention, either in Nuremberg (Germany) or in Milan (Italy), of the wheel lock, in which a piece of pyrite attached to a short hammer, the so-called "cat's foot", produced sparks when it hit a spinning disc or springloaded wheel (Solinas 1971). The last third of the $16^{\text {th }}$ century saw the invention of a form of wheel lock in which a piece of flint, chert or pyrite struck a spike on a rake (a piece of fluted steel). This system was called the flint lock or snaphaunce in Dutch (Borja Pérez 1997). In parallel, in Spain appears the 'miquelet' or Spanish lock, a new system based in the ability to produce flint sparks (Borja Pérez 1990; Morgado \& Roncal 2009: 76). At the beginning of the $17^{\text {th }}$ century, the spark lock was introduced in France (Rodríguez Hernández 2016). This fixed the flint or chert on a spring attached to the hammer that was violently projected against the steel or platinum rake, which was fixed in an arrangement perpendicular to the pan that contained the gunpowder. The most recent system, which is still in force today, is that found in automatic weapons, which, by a percussion system, acts as a fulminating capsule (Barandiarán 1974).

At the beginning of the $18^{\text {th }}$ century, the production of gunflints in the Iberian Peninsula was not centralized in specific production centres as was the case in England (e.g., Brandon, in the county of Suffolk) (Clarke 1935; Whittaker 2001; among others) or France (e.g., Meusnes, Loir-et-Cher Department) (Barnes 1937; Stevenson et al. 2007; among others). In Spain, the main production centres and artisans were located in the Ebro valley (Aragon, Catalonia and various places in the region of the Basque Country) and in the eastern part of Andalusia (in the Baetic mountain ranges, mainly Granada and Malaga), where an abundance of good quality supplies of this raw material were present (Morgado \& Roncal 2009: 136137). In Catalonia, for example, the Conca de Barberà region (Tarragona) was an area where this type of work was carried out, with the towns of Vilaverd and Lilla being among the most 
outstanding locations due to the abundance of this raw material. However, from the second half of the $18^{\text {th }}$ century onwards, this situation changed with the establishment of a regulated system between the crown and the knappers. Thus, there came to be various main production centres, such as those in the valley of the Huerva river (Zaragoza) or in the eastern part of Andalusia (Morgado \& Roncal 2009: 146; Roncal et al. 1996).

Two exploitation systems have been identified over the course of the period of gunflint production in the Iberian Peninsula: i) from the beginning of the $18^{\text {th }}$ century, centripetal strategies were used to obtain short, thick flakes that were consequently retouched until a quadrangular morphology was obtained ideal for gunflints (Barandiarán 1974); these cores have the appearance of the typical Levallois or discoidal ones from the Middle Palaeolithic; and ii) from the first quarter of the $19^{\text {th }}$ century, laminar strategies were used to obtain long blades and thus gunflints that were trapezoidal in section; this was the so-called "French method" and produced the typical prismatic morphologies of the cores (Roncal et al. 1996; White 1975).

In order to characterize a newly-discovered, previously unknown chert quarry exploited in historical times, this work has the following objectives: 1) to undertake a petrographic characterization of the chert of La Guinardera Quarry; 2) to produce a technological characterization of the LGN Workshop; and 3) to identify the distinctive characteristics of a gunflint workshop that differentiate it from prehistoric workshops.

\section{Materials and Methods}

\subsection{The Guinardera Quarry}

The Guinardera chert quarry is made up of several chert locations in primary (inside the enclosing rock) and sub-primary (few metres from the enclosing rock due to erosive processes) positions, and at least two workshops for the production of lithic tools: La Guinardera and La Guinardera Nord. These outcrops are located in the NE Iberian Peninsula, to the SW of the town of Sant Martí de Tous (Anoia, Barcelona), $50 \mathrm{~km}$ from Barcelona. The UTM (ETRS89) coordinates for La Guinardera are 375374 E; 4600726 N and $519 \mathrm{~m}$ a.s.l., and for La Guinardera Nord 375317 E; $4601036 \mathrm{~N}$ and $523 \mathrm{~m}$ a.s.l. (Figure 1). The two quarries are located on two different slopes on a small hill, named 'Serral dels Concos', 300 $\mathrm{m}$ apart from each other and in the vicinity of farmlands. On top of the hill, we located a chert outcrop in primary position and another two in different stratigraphic positions. The chert found in the studied quarries came from the dismantling of these outcrops. Materials appear on the surface, occasionally mixed with remains from different periods and with natural blocks. These facts hinder chrono-cultural adscription.

\subsection{Geological Setting}

The Guinardera Quarry is located in one of the marginal basins of the Catalan central depression of the Ebro Basin: the Anoia Basin. From a geological point of view, it is situated in the Sant Genís Formation, which is of Priabonian (upper Eocene) age and forms part of La Noguera lacustrine system (Anadón et al. 1989), under the denomination of Upper Grey Lutites (Sáez 1987: 60). Currently, the Sant Genís Formation is exposed over a maximum 1.5 $\mathrm{km}$ width and is $12 \mathrm{~km}$ long, with a NE-SW orientation, running from the locality of Sant Genís (Jorba) through to the locality of Fillol (Sant Martí de Tous); it covers a surface area of ca. $5,600,000 \mathrm{~m}^{2}$. It is formed by a succession of $400 \mathrm{~m}$ of sandy lutites of red and sporadically grey colour (5R 4/6 Moderate Red and 5Y 5/2 Light Olive Grey respectively) (Munsell Color 2013), with horizontal lamination and ripples, interspersed with sporadic limestone layers with charophytes and gastropods (Colldefons et al. 1994). In the cartographic 
maps it is divided between two formations; one formed by red sandstones and marls, and the other by grey sandstones and marls, with local stratified gypsum (Peón \& Alonso 1975) (Figure 2).
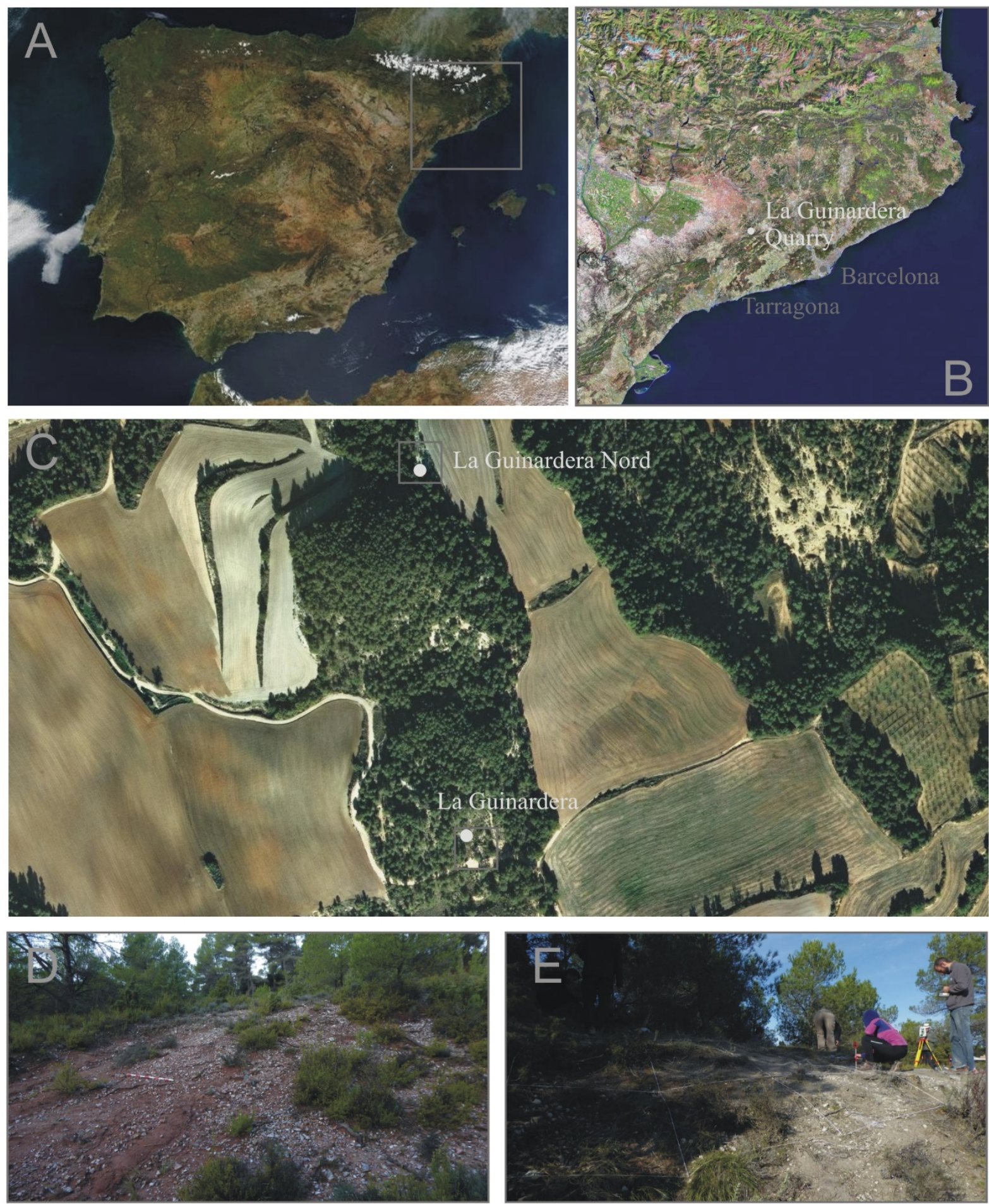

Figure 1. A and B) Location of La Guinardera Quarry in the Iberian Peninsula and the Catalonian region. C) The two workshops in an orthophotomap. D) La Guinardera Workshop. E) La Guinardera Nord Workshop. 


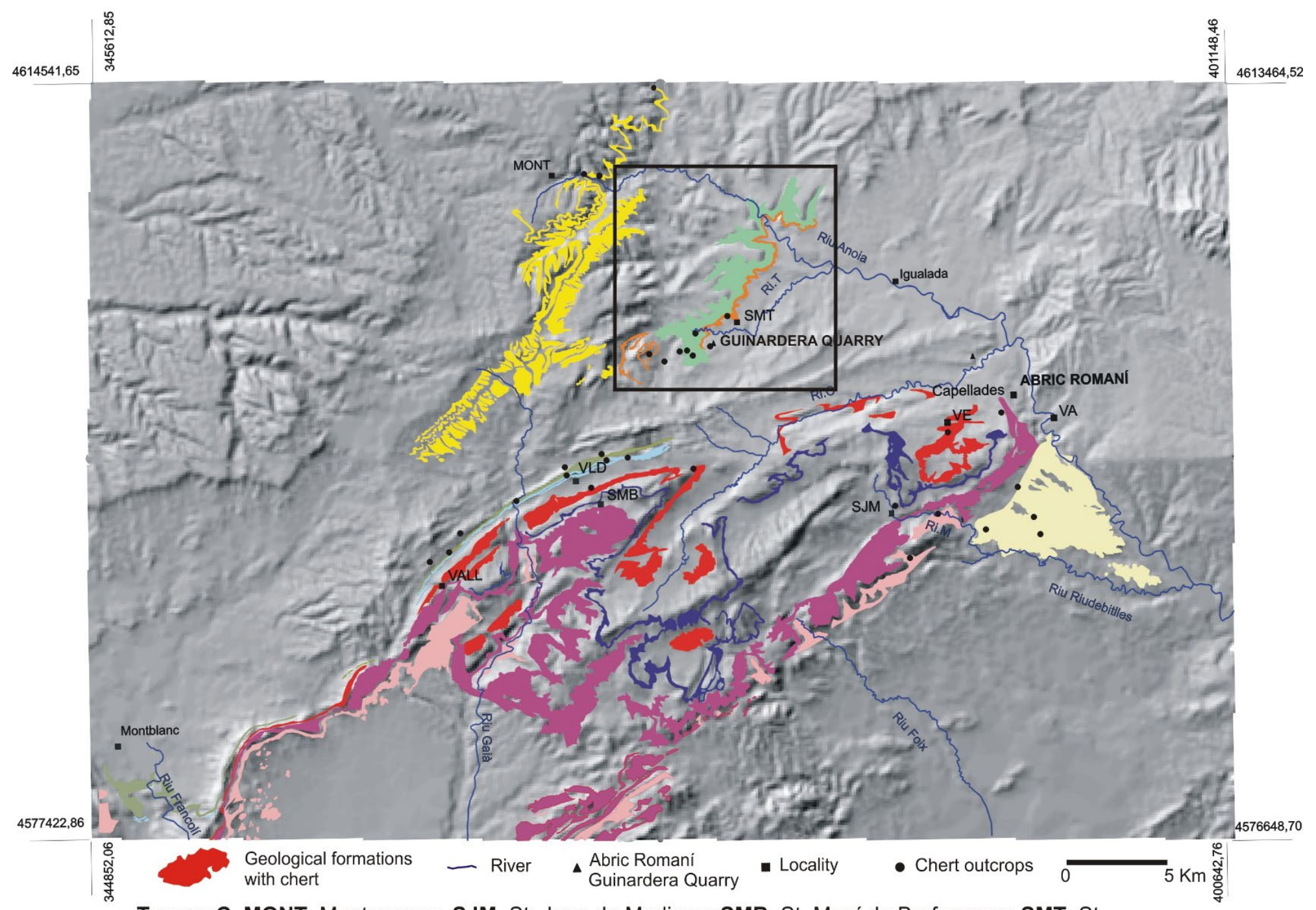

Towns: C, MONT, Montmaneu; SJM, St. Joan de Mediona; SMB, St. Magí de Brufaganya; SMT, St. Martí de Tous; VALL, Vallespinosa; VLD, Valldeperes; VA, Vallbona d'Anoia; VE, Vilanova d'Espoia.

Figure 2. Geological formations containing cherts on the eastern margin of the Ebro Basin and the location of the archaeological site mentioned in the article upon the digital terrain elevation model $(1: 50,000)$. In the black box, the Sant Genís formation and the Guniardera Quarry (modified from Gómez de Soler et al. 2020a). 
The stratigraphic sequence in the Sant Martí de Tous area is characterized by an exposed thickness of $100 \mathrm{~m}$, divided from top to base into $20 \mathrm{~m}$ of gypsums, followed by $80 \mathrm{~m}$ of alternating grey and red lutites, marls, red sandstones and sporadic gypsums, both yielding interspersed chert nodules (Gómez de Soler 2016: 87). Different sectors with chert exposures have been located, but we will focus on the Guinardera quarry, namely the Guinardera Sector. In this sector two synthetic stratigraphic sequences are presented: the Cal Perdut section (chert outcrops of Cal Perdut 1, 2, 3, 4 and Mas de Tous) and the Guinardera section (chert outcrops of Guinardera 1, 2 and 3) (Figure 3).

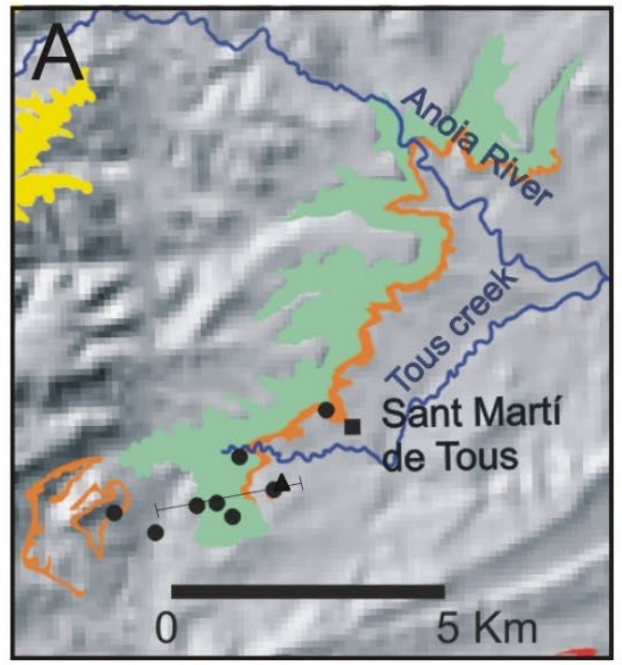

- Guinardera Quarry

- Chert locations Stratigraphic profiles

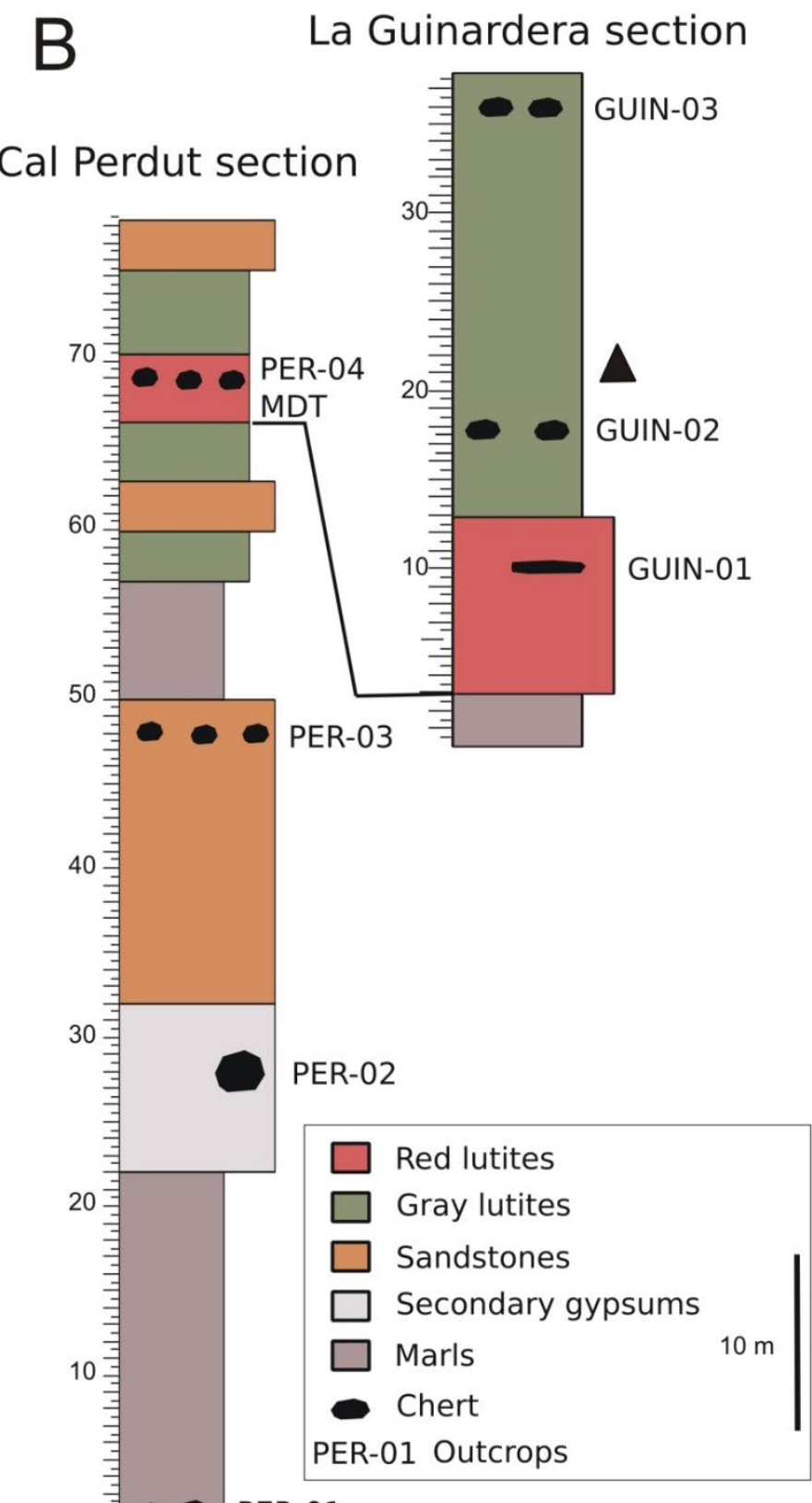

PER-01

Figure 3. A) Detail of the Sant Genís Formation and the location of the Guinardera Quarry. B) Synthetic lithostratigraphic sequence of the Sant Genís Formation in the Guinardera Quarry and the stratigraphic position of the different located chert layers (synthetic stratigraphic sequences by B. Gómez de Soler). 
The Cal Perdut section comprises an $80 \mathrm{~m}$ sequence. It presents $20 \mathrm{~m}$ of white marl limestones with nodular cherts (Cal Perdut 1). The following layer is formed by $2 \mathrm{~m}$ of secondary gypsums where meganodular cherts are present (Cal Perdut 2). Following this layer, $15 \mathrm{~m}$ of calcarenitic limestones with chert nodules at the top is present (Cal Perdut 3). At the top a layer formed by alternating marls, green and red lutites, and calcarenitic limestones is described, with chert in both lutite events (Cal Perdut 4 and Mas de Tous chert outcrops).

The Guinardera section comprises a $40 \mathrm{~m}$ sequence. At the base, corresponding to the top of Cal Perdut, there are $10 \mathrm{~m}$ of red lutites with sporadic red sandstones with a tabular chert (Guinardera 1); this is followed by $30 \mathrm{~m}$ of grey lutites with chert at the base and top of this layer (Guinardera 2 and 3).

The Guinardera Quarry is found in a stratigraphic position between the chert exposures GUIN-01 and GUIN-02 and feeds on the dismantling of both locations providing chert in a sub-primary position.

\subsection{Data Collection}

Fieldwork was carried out between 17 and 31 October 2018. The first step was the systematic collection of lithic material in specific areas of each workshop. For La Guinardera, we delimited an area of $8 \mathrm{~m}^{2}$, and for La Guinardera Nord, an area of $25 \mathrm{~m}^{2}$. After creating a square-metre grid, we started to collect all the material larger than $2 \mathrm{~cm}$ and with clear signs of knapping activity with the intention of generating the least possible noise to the recovered set, focusing on that material that presented clear anthropic knapping evidences (e.g., percussion platforms, bulbs, artifacts with previous scars on dorsal faces) on the surface. We also carried out a small excavation in La Guinardera to verify that all the material appeared only on the surface (Figure 4).
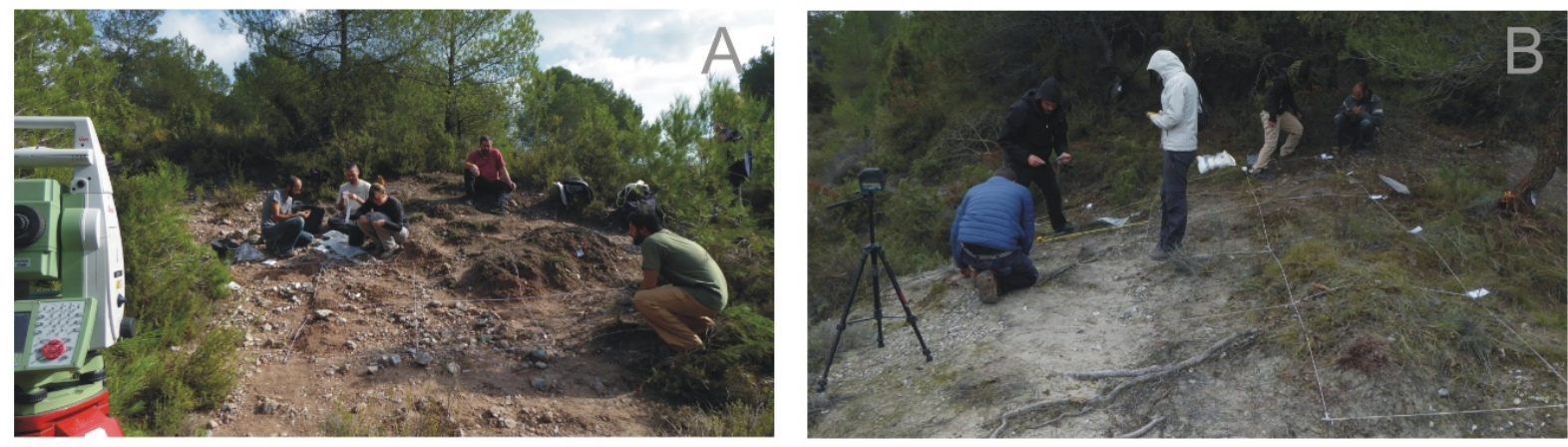

Figure 4. A) View of the excavation of La Guinardera Workshop. B) View of the excavation of La Guinardera Nord Workshop.

For the data collection, we used the Cartesian coordinate system (Laplace \& Meroc 1954), coordinating the material with a total station and registering the material through the ARCHE 2.0 application, an inventory system based on Windows XP in the form of a script compatible with any web browser (ARCHE 3.0). The ARCH-E system comprises a record sheet that is on the PDA and that incorporates the basic characteristics of the described inventory, which is used for the archaeological record of the sites studied by the IPHES (Canals et al. 2008). All these data are entered automatically into a data processor (Excel), which allows the data to be organized in addition to providing for lists and statistical analysis of the inventoried material. 
All the collected material was cleaned with water and without using abrasive products, with the intention of observing the material from a traceological point of view; and it was individually labelled.

\subsection{Lithic analysis}

For the lithic analysis we follow the proposals put forward by Morgado \& Roncal (2009: 232-233, 251-265) and Ballin (2012) for the study of gunflint workshops. The materials are classified as blocks, cores, flakes, flake fragments, blades, blade fragments, tools (retouched, gunflint preforms and gunflint) and indeterminate pieces. Indeterminate pieces are those produced by the quartering or flaking process but without a clear morphology assignable to one of the above-mentioned categories. Gunflint preforms are those flakes or flake fragments that present a certain investment of work with some modifications at the edges, and morphologies close to the final products (quadrangular forms and triangular or trapezoidal sections) or pieces fractured during the configuration processes. Gunflints are characterized in line with the morphology and the type of retouching according to Ballin (2012), Morgado \& Roncal (2009: 96-103) and Merino (1965). Following the description of Merino (1965), nine types are defined, but like Morgado \& Roncal (2009: 107) we introduce two variants within type 6 ( $a$ and $b$ ): those on flake that have triangular sections, also called "Spanish type" (6b), and those on blades that have trapezoidal sections due to the "back" or "platform" at the upper face, also called "French type" (6a) (Austin 2020); these were introduced into the Iberian Peninsula during the first half of the $19^{\text {th }}$ century (Roncal et al. 1996) (Figure 5).

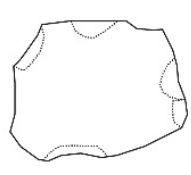

1

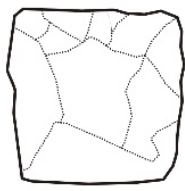

$6 a$

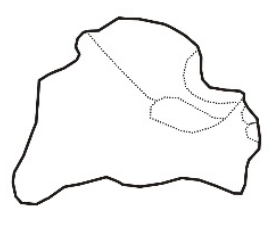

2

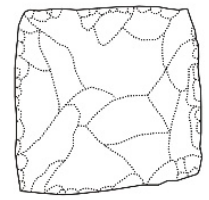

$6 b$

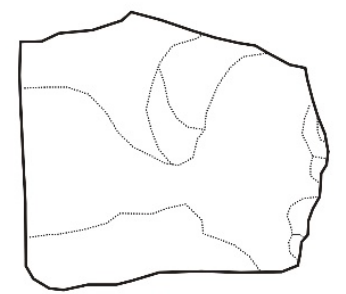

3

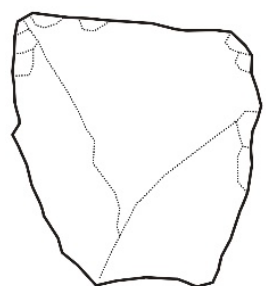

7

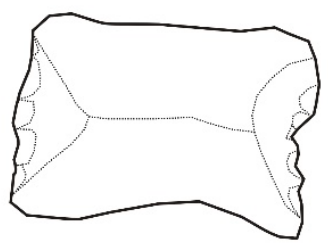

4

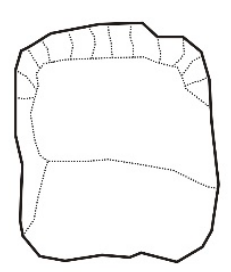

8

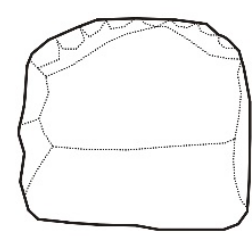

5

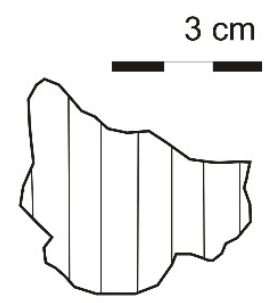

9

Figure 5. Different morphologies and types of gunflints. Based on Merino (1965) and Barandiarán (1974).

The typometric analysis is based on Ballin (2012) for the elongation index, counting as blades those whose length is twice the width, and as microblades those whose width is less than $8 \mathrm{~mm}$. For the carination index, we follow Laplace (1972), dividing the smallest of the flat dimensions (length or width) by its thickness. A carinated object offers indexes lower than 2.23, and flat artefacts exceed this ratio.

Cores were analysed by identifying the supports and reduction systems present in the assemblage (Roncal \& Morgado 1999). On the basis of these criteria, we establish six technotypological categories: prismatic, discoidal, polyhedral, pyramidal, on flake and amorphous.

Finally, certain materials were examined with a Hirox KH-8700 3D digital microscope at low magnification, with the aim of locating and documenting the presence of oxides on the 
exploitation surfaces of the cores and on the percussion platforms and ventral parts of the products.

\section{Results}

As pointed out above, we here focus on the data from La Guinardera Nord (LGN), since it presents a homogeneous assemblage.

The assemblage of LGN is formed by 470 analysed objects of chert (100\%), collected within an area of $25 \mathrm{~m}^{2}$ on the slope of the hill (Figure 6). Most of the material was grouped in this area but we also observed material scattered throughout the slope and the surrounding fields.

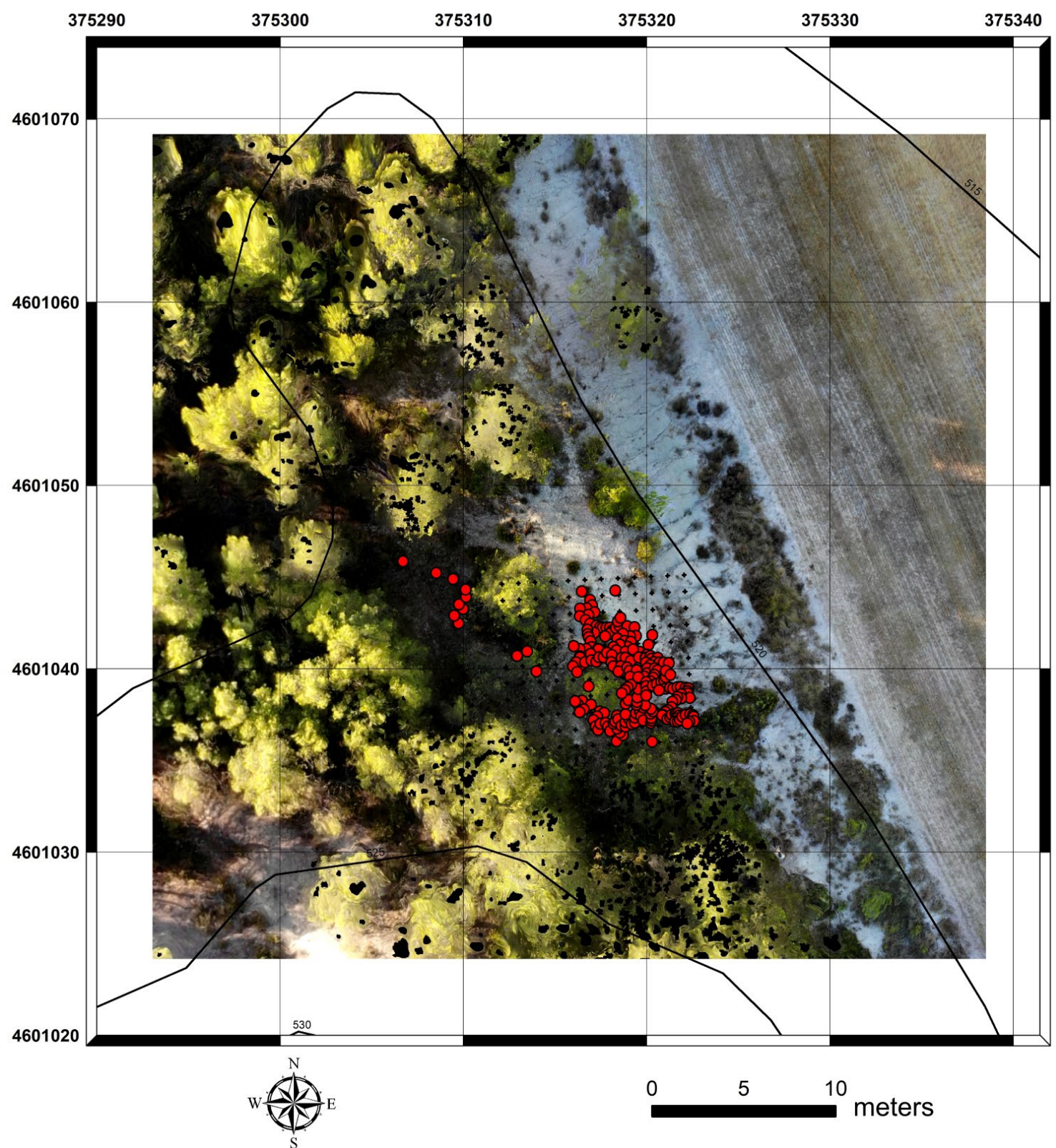

Figure 6. Orthoimage of the Guinardera Nord Workshop, obtained with a Dji Maverick drone. The figure also illustrates the area involved and the dispersion of the registered materials (red dots with the circle in black). 

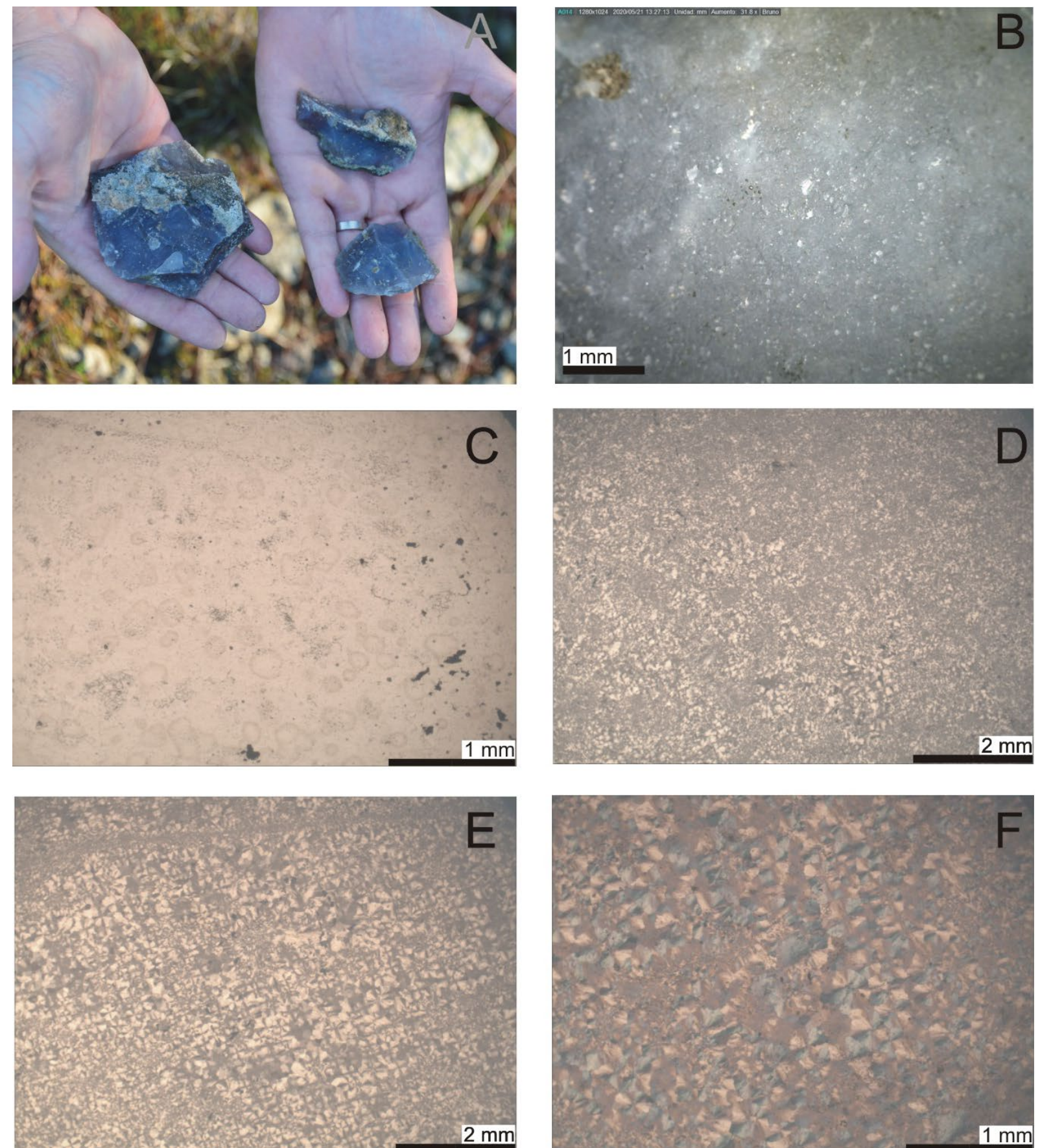

Figure 7. A) Some of the archaeological assemblage collected during the fieldwork, showing its homogeneous colour and macroscopic texture. B) Detail of the archaeological sample LGN'18_sup_D29_8 taken with the stereomicroscope Dino-Lite Pro AD4113T. The fine texture is observed, as are some isolated iron oxides and carbonates. C, D, E \& F) Different images of a thin-section, taken under a petrographic microscope, of a block from La Guinardera Quarry (LGN'18_sup_D29_5). C) Spherulitic structures under plane-polarized light (PPL) at 40x. D) Microcrystalline quartz and length-slow chalcedony matrix under cross-polarized light (XPL) at 20x. E) Length-slow chalcedony matrix under XPL at 20x. F) Identification of the elongation of the fibrous silica length-slow chalcedony - by the accessory wedge of $1 \chi$ at $40 x$ (XPL \& accessory wedge of $1 \chi$ ).

Macroscopically, the chert has homogeneous greyish colours (5PB 5/2 Greyish Blue and 5PB 7/2 Pale Blue) (Munsell Color 2013), with dark hues and an opaque diaphaneity but translucent at the edges. Its texture is fine, with scarce fissures, absence of patina or concretions as post depositional alterations and relatively fresh edges. The cortex, when present, is thin, not gradual and angular, preserving the attributes of its enclosing rock. 
Microscopically, it is a homogeneous chert formed basically by microcrystalline quartz matrix (35-45\%), with spherulitic length-slow chalcedony (35-45\%) and some secondary gypsum (1-3\%). By contrast with the current carbonated enclosing rock, this length-slow chalcedony, typical of sulphated environments (Arbey 1980; Bustillo 1976; Cayeux 1929), suggests its evaporitic origin from sabkha environments characteristic of the Sant Genís Formation (Ortí et al. 2007). As cement of secondary porosities, we have megaquartz (1\%) in vugs, and microcrystalline quartz (3-5\%) in fractures and channels. Disseminated sparitic (1$3 \%)$ and micritic (1-3\%) carbonates, probably related to drying episodes in which these would have replaced the primary gypsum of the original matrix, form the current enclosing rock, a common phenomenon in lake margin areas (Ortí et al. 2007). As an accessory mineral, haematite is present (2-4\%) (Figure 7).

From a technological point of view, the assemblage shows a predominance of flake fragments, followed by flakes, indeterminate pieces, tools, cores, blades, blocks and blade fragments (see Sections 2.3 and 2.4) (Table 1).

Table 1. Categories of the analysed materials.

\begin{tabular}{lll}
\hline Categories & Number & \% \\
\hline Blocks & 21 & 4.5 \\
Cores & 22 & 4.7 \\
Flakes & 122 & 26 \\
Flake fragments & 160 & 34 \\
Blades & 21 & 4.5 \\
Blade fragments & 19 & 4 \\
Tools & 43 & 9.1 \\
Indeterminate & 62 & 13.2 \\
\hline Total & $\mathbf{4 7 0}$ & $\mathbf{1 0 0}$ \\
\hline
\end{tabular}

Flakes and flake fragments are predominant. The flakes are characterized by being large, shorter and thick, with morphologies generally quadrangular, and triangular or trapezoidal sections (Table 2). The carination index shows us that a $41.3 \%$ of flakes and blades $(n=143)$, are carinated objects (Table 3). The butt is unifaceted, with a thick platform and generally with the percussion point marked. The ventral part has pronounced bulbs, and in most cases a Hertzian cone and other parasitic flakes are present. In general, these characteristics indicate on the one hand the use of a very hard hammer and on the other a search for predetermined shapes. These traits are also documented among the blades, except for their rectangular morphology. Most of the flakes and blade fragments present a transverse and or oblique fracture, at the distal edge, at the proximal edge, or both. This characteristic is very common, and suggests that specific morphologies are desired, since the fractures seem intentional, some of them being possible gunflint blanks (Barnes 1937). These morphologies remain quadrangular or rectangular, with triangular or trapezoidal sections (Figure 8).

Table 2. Measures in millimetres of central tendency (average) and standard deviation for the 143 flakes and blades.

\begin{tabular}{lcccc}
\hline & Minimum & Maximum & Average & Standard deviation \\
\hline Length & 10 & 86 & 39.9 & 15.2 \\
Width & 10 & 110 & 34.8 & 14.4 \\
Thickness & 3 & 44 & 12.4 & 5.8 \\
\hline
\end{tabular}


Table 3. Carination index for flakes and blades.

\begin{tabular}{lcc}
\hline & Number & \% \\
\hline Carinated & 59 & 41.3 \\
Non-Carinated & 84 & 58.7 \\
\hline Total & $\mathbf{1 4 3}$ & $\mathbf{1 0 0}$ \\
\hline
\end{tabular}

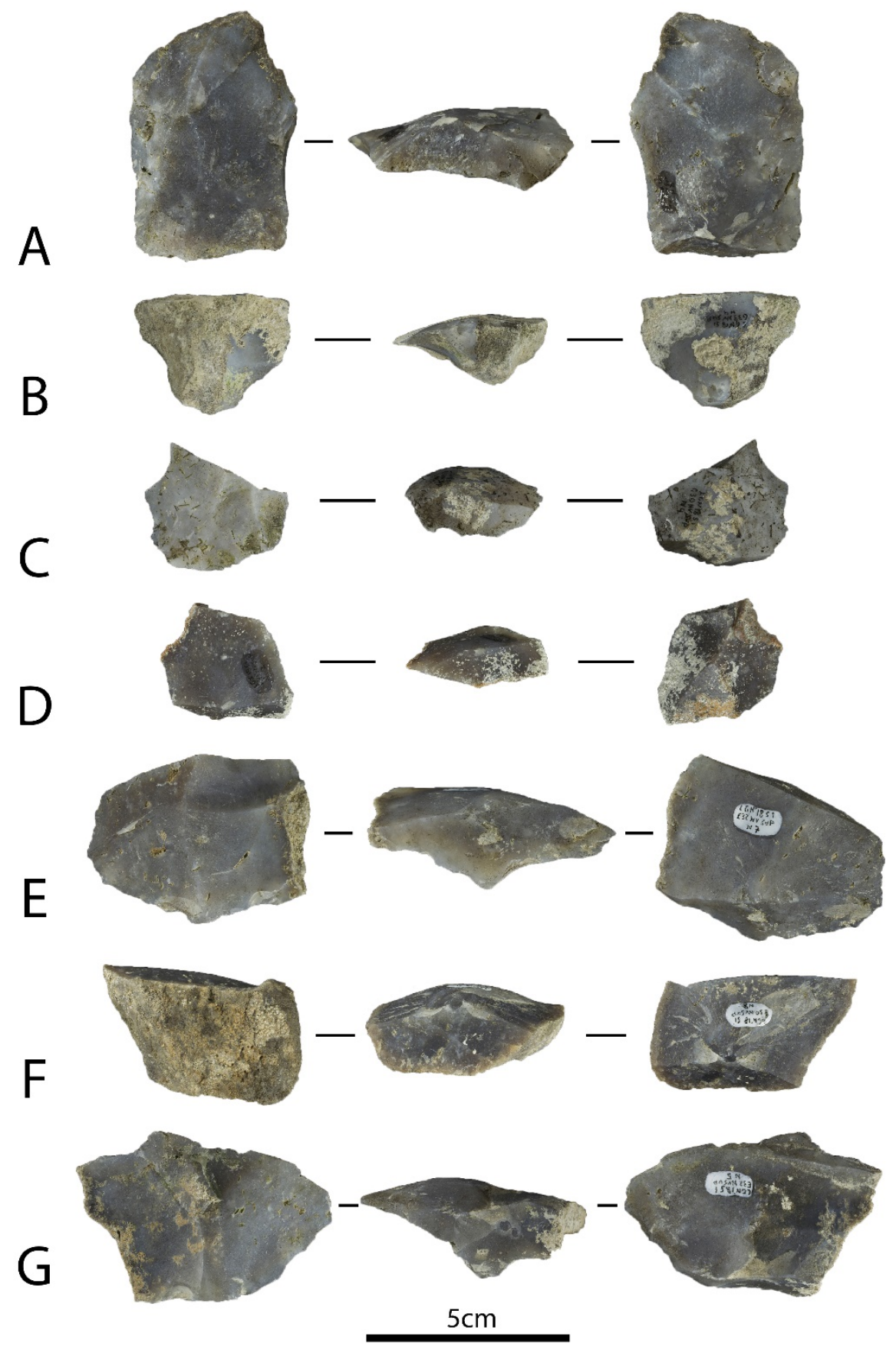

Figure 8. Some archaeological flakes and flake fragments with attributes that indicate the search for standardized forms and percussion with a hard hammer (iron). A) Large flake with a thick butt and a marked bulb (LGN'18_sup_D29_8). B) Flake fragment with distal transverse fracture (LGN'18_sup_G33_4). C) Flake fragment with an oblique fracture (LGN'18_sup_G30_4). D) Flake fragment with a distal transverse fracture (LGN'18_sup_I31_2). E) Flake fragment with a distal transverse fracture and with the point of impact very marked (LGN'18_sup_E32_7). F) Decorticate flake fragment with a distal transverse fracture, thick butt, marked bulb and point of impact (LGN'18_sup_E30_8). G) Flake fragment with a distal transverse fracture, thick butt and marked bulb (LGN’18_sup_E32_5) (Photographs by M. D. Guillén). 
The core supports are those provided by the source area (dismantled tabular blocks from the primary source) and large format flakes. We have documented a total of 22 cores, representing $4.7 \%$ of the total set. At a techno-typological level, the most highly represented are polyhedral, followed by discoidal and on flake (Table 4). Most of the cores are in an initial phase $(n=10)$ or in a full exploitation phase $(n=10)$, and only two are in a final phase. The knapping faces are mostly bifacial $(n=11)$, with multipolar centripetal removal dispositions, followed by those that are unipolar. In general, it cannot be said that there is standardization in the exploitation strategies, but rather an expeditious and opportunistic production (Figure 9).

Table 4. Types of cores.

\begin{tabular}{lcc}
\hline Cores & Number & \% \\
\hline Prismatic & 3 & 13.7 \\
Discoidal & 5 & 22.7 \\
Polyhedral & 6 & 27.3 \\
Pyramidal & 1 & 4.5 \\
On flake & 5 & 22.7 \\
Amorphous & 2 & 9.1 \\
\hline Total & $\mathbf{2 2}$ & $\mathbf{1 0 0}$ \\
\hline
\end{tabular}

As the flaking products show, the cores confirm the search for flakes and non-laminar products. The one pyramidal core and the three prismatic cores show unipolar strategies, with negatives of flakes and none of blade proportions. In general terms, there was a low percentage of cores in the assemblage, given that it is a quarry context. A possible explanation could be that some of the cores were taken by the knappers to other places. This hypothesis is supported by the fact that there are few cores in a final state of exploitation.

As regards the gunflints, the assemblage is composed of gunflint preforms rather than finished gunflints, some with very well-defined morphologies but without complete preparation of the sides, the leading edge and heel (Ciarlo et al. 2019). As noted by Ballin (2012), the sides and the heel are usually modified by retouch, whereas the leading edge sometimes appears unmodified. In the LGN assemblage the retouch is sparse and usually reduced to one side, justifying their classification as gunflint preforms (Figure 10).

In attempting to classify these preforms, we followed Merino (1965), despite being aware that there are no finished tools, its morphology can be adjusted to the gunflints' types proposed. The 43 tools are grouped into gunflint preforms $(\mathrm{N}=35)$ and retouched indeterminate $(\mathrm{N}=8)$ (Table 5). Retouched indeterminate tools are those presenting some marginal and discontinuous retouch on any side, without a determinate morphology. Of the gunflint preforms, the most highly represented is type 1 , which corresponds to thick flakes with flat, rectangular faces, with fabrication and use-retouched on some of its edges or sides. These are followed by type 5 , type 7 and type $6 \mathrm{~b}$, with the same number of each. Type 5 are rectangular flakes or blades that present abrupt retouches on the sides. Type 7 are trapezoidal flakes that simulate Mousterian points or small converging scrapers, with retouches on the side opposite the percussion bulb, which is either preserved or removed. Type $6 \mathrm{~b}$ are quadrangular flakes, with triangular sections, without a platform on the upper face, with a truncated or dull vertex, retouched on some of the dorsal face and with a flat base. The last of the more abundant categories is type 4, comprising thick rectangular flakes or blades, with one or two arises on its upper face, and adjustment retouches on the sides, edges or heel. The rest of the types are represented by no more than two objects and in no case exceed $6 \%$ of the gunflint preforms. 

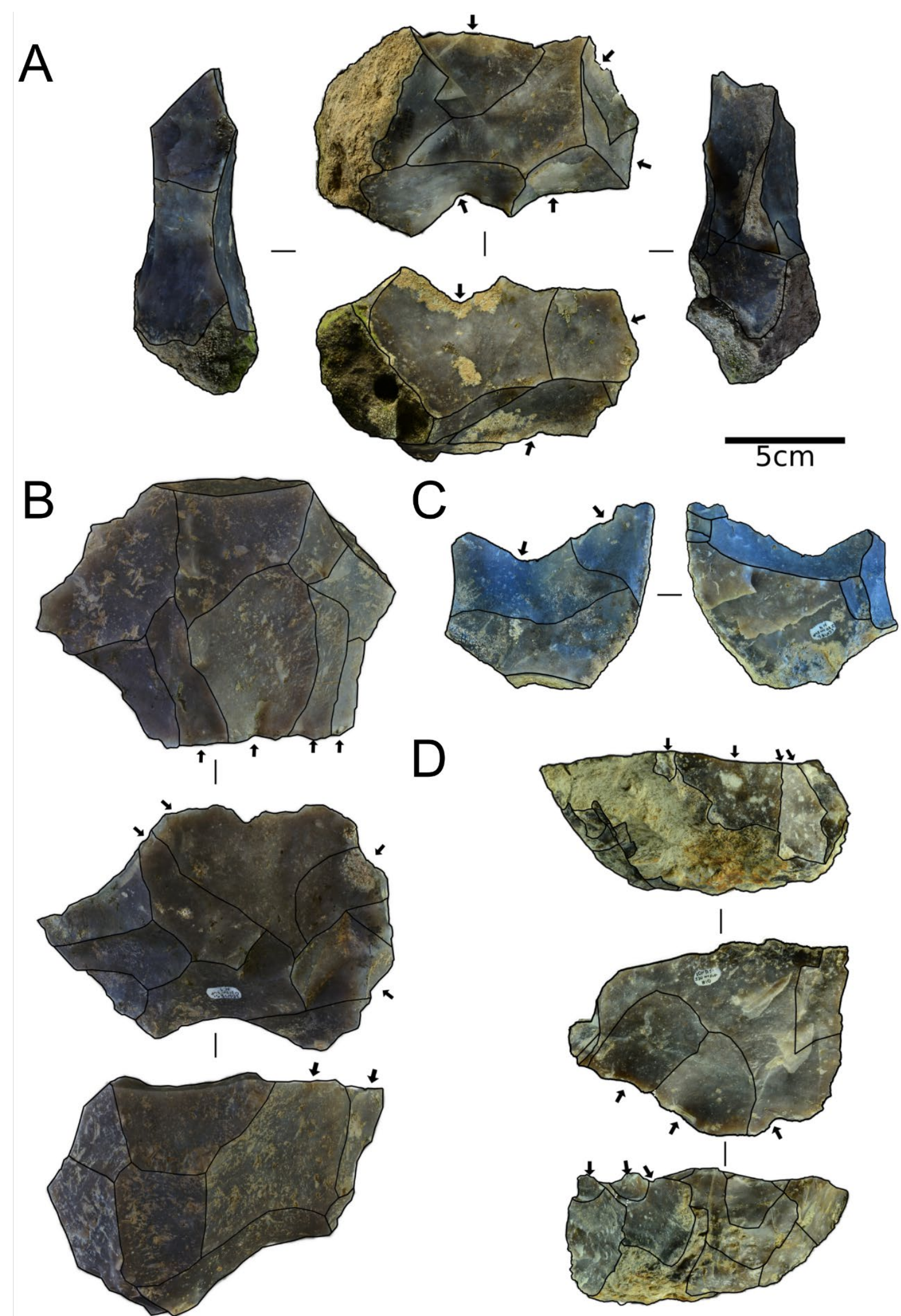

Figure 9. Some cores form LGN. A) Discoidal core LGN'18_sup_L20_2. B) Polyhedral core LGN'18_sup_D31_1. C) Core on flake LGN'18_sup_I30_4. D) Discoidal core LGN'18_J30_10 (Drawings and photographs by M. Soares-Remiseiro). 

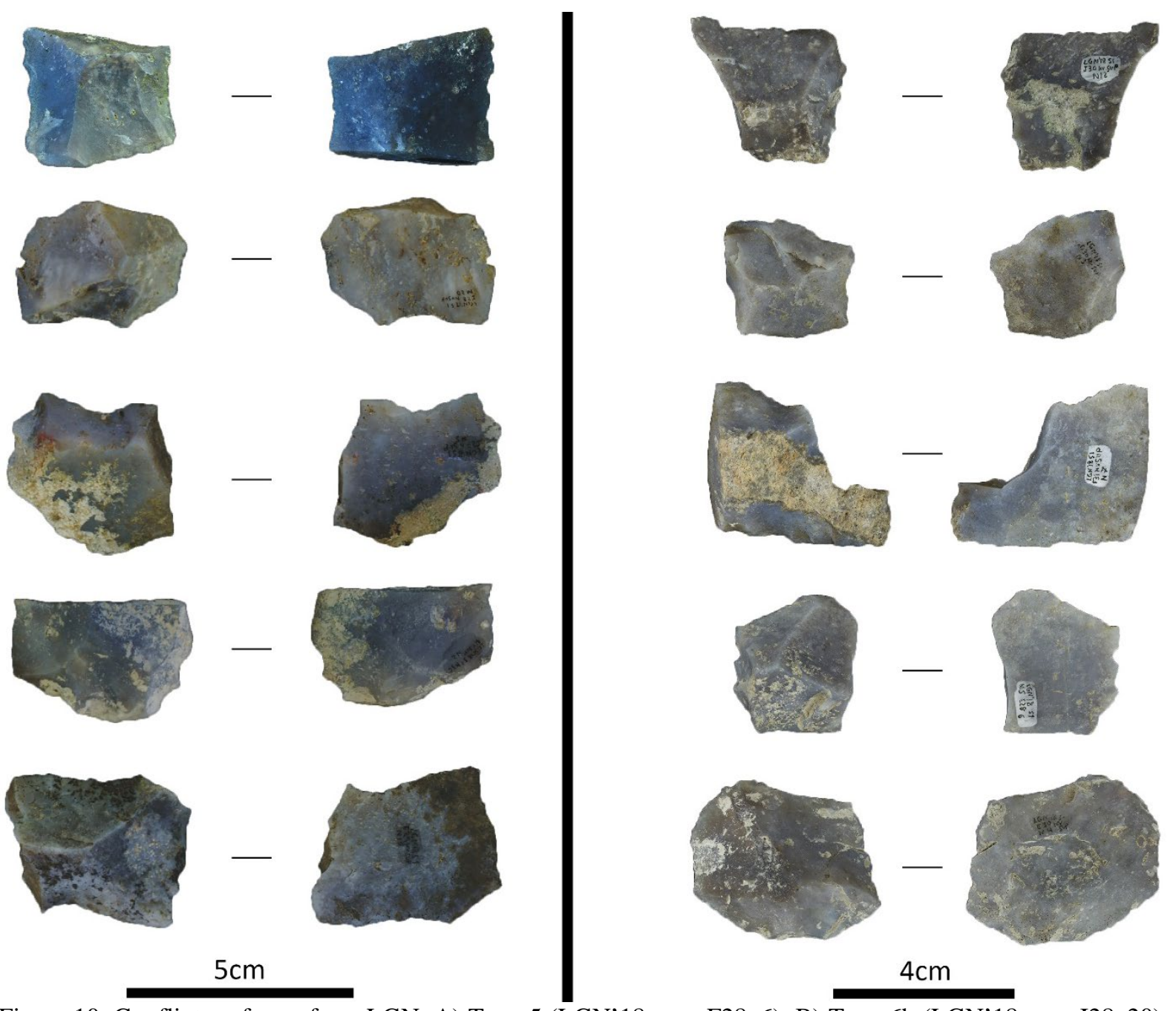

$4 \mathrm{~cm}$

Figure 10. Gunflint preforms from LGN. A) Type 5 (LGN'18_sup_F28_6). B) Type 6b (LGN’18_sup_I28_20). C) Type 5 (LGN'18_sip_I27_5). D) Type 6b (LGN'18_sup_K30_2). E) Type 4 (LGN'18_sup_E29_16). F) Type 4 with a fabrication fracture (LGN'18_sup_J30_12). G) Type 6b (LGN'18_sup_G30_5). H) Type 6a with a fabrication fracture (LGN'18_sup_F31_7). I) Type 6b (LGN'18_sup_E28_6). J) Type 6b with a parasitic flake in the lower face (LGN'18_sup_E30_4) (Photographs by M. D. Guillén).

Table 5. Type of tools.

\begin{tabular}{lccc}
\hline Tools & \multicolumn{3}{c}{ Number } \\
\hline Gunflint preforms & & $\mathbf{3 5}$ & $\mathbf{8 1 . 4}$ \\
\cline { 2 - 4 } & Type 1 & 7 & 20 \\
& Type 2 & - & - \\
& Type 3 & 2 & 5.7 \\
& Type 4 & 3 & 8.7 \\
Type 5 & 6 & 17.1 \\
& Type 6a & 2 & 5.7 \\
& Type 6b & 6 & 17.1 \\
& Type 7 & 6 & 17.1 \\
& Type 8 & 2 & 5.7 \\
& Type 9 & 1 & 2.9 \\
\cline { 2 - 4 } & Total & 35 & 100 \\
\hline Retouched indeterminate & & $\mathbf{8}$ & $\mathbf{1 8 . 6}$ \\
\hline Total & & $\mathbf{4 3}$ & $\mathbf{1 0 0}$ \\
\hline
\end{tabular}

Journal of Lithic Studies (2021) vol. 8, nr. 2, 24 p. 
Analysis of the LGN materials also revealed a series of technical attributes indicative of the use of metal hammers for the production of the assemblage. The presence of flakes with thick platforms, unfaceted butts, with a marked Hertzian cone and parasitic flakes on the ventral face corroborates this (see Figure 8). The presence of cores with a very marked bulbar scar and highly pronounced, striking platform negatives also indicates direct percussion with a hard hammer (Figure 11A). Analysis of the surfaces under a digital microscope (Hirox KH8700 3D) brought to light the presence of oxides associated with impacts on the striking platforms, as well as on the surfaces of some artefacts, corroborating the use of iron hammers (Figure 11B).
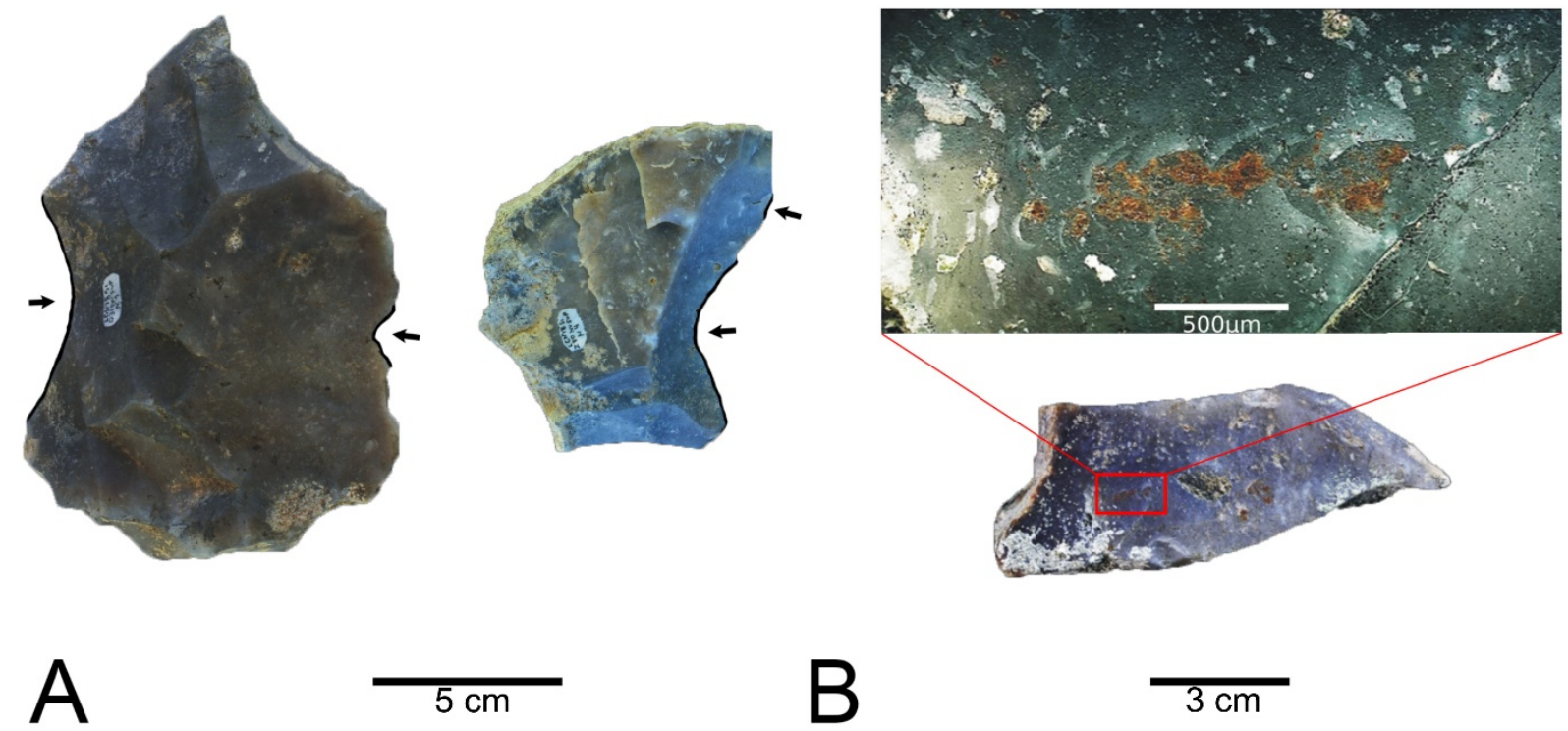

$$
3 \mathrm{~cm}
$$

Figure 11. Evidence of the use of metal hammers. A) Wide flake mouths and large bulbar scar. Left, polyhedral core LGN'18_sup_D31_1; right, core on flake LGN'18_sup_I30_4. B) Oxidation and percussion cones observed through the microscope (LGN'18_sup_H31_4) (Photographs by J. L. Fernández-Marchena).

\section{Discussion}

Identification of a new chert location is always important to have a better knowledge of the territory and its resources. The presence of this type of chert in the nearby Middle Palaeolithic site of Abric Romaní (16 km to the SE) (Gómez de Soler 2016: Chapter 8 \& 9; Gómez de Soler et al. 2019; 2020a), in the neighbouring Neolithic campsite of Els Vilars de Tous (Sant Martí de Tous, Barcelona) (Clop et al. 2005), in the various chert workshops in the same town assigned to the Bronze Age (Cámara 2017; Enrich 1981), and now in the LG and LGN Workshops, confirms the exploitation of this territory and this raw material, more or less continuously, right though from prehistory to at least modern times, a common aspect in many chert-rich territories (Palomo \& Gibaja 2006).

The presence of centripetal bifacial reduction systems can lead to erroneous chronological adscription. These reduction systems are present in sets from the Lower Pleistocene to the present day, and the appearance of centripetal cores could lead to confusion with Palaeolithic complexes (Barandiarán 1974; Morgado \& Roncal 2009: 36; Roncal et al. 1996). Our initial project was to focus on the location of chert quarries and workshops that could have been exploited by the Neanderthals occupying Abric Romaní, situated $16 \mathrm{~km}$ to the southeast of the LGN locality (Gómez de Soler 2016: 211-265; Gómez de Soler et al. 2019; 2020a). At the beginning of the 2018 fieldwork campaign, the lithic assemblage recovered at LGN, with its homogeneous features, initially brought old chronologies to mind. However, as we collected the material, our recognition of a series of attributes (e.g., fresh 
edges, flakes with marked bulbs and thick platforms, cores with a bulbar scar, the nearabsence of patinated material) led us to ascribe them to historical times as other similar workshops (Sánchez de la Torre et al. 2016). The fact that not gunflints but preforms were recognized was no help in achieving a correct attribution at the beginning. For this reason, in this preliminary study a series of traits are proposed to make it easier to identify these kinds of remains.

Most of the flaking elements show some common characteristics: i) the search for thick supports; ii) rectangular or quadrangular morphologies, either naturally or with distal, proximal or oblique transverse fractures; and iii) triangular or trapezoidal sections. The cores show no standardized reduction strategy (e.g., discoidal, polyhedral, prismatic cores). However, most of them show the extraction of flakes and non-laminar products in the simplest way. The presence of use marks observed through the microscope, oxide traces on butts and ventral faces of flakes and blades, and the very marked bulbar scar and highly pronounced, striking platform negatives in cores, demonstrates the use of a metal hammer.

All these characteristics identify the LGN assemblage as a set derived from the quartering, flaking and knapping process in search of spark stones, as has also been well documented in other workshops in the Iberian Peninsula (Barandiarán 1974; Merino 1965; Millán et al. 2020; Morgado \& Roncal 2009: Chapter 1, 4 \& 5; Roncal et al. 1996; Roncal \& Morgado 1999), elsewhere in Europe (Ballín 2012; Clarke 1935; Fowler 1992; Woodall \& Chelidonio 2005) and in America (Schavelzón 2013: 78).

In one of the most extensive and well-documented works on gunflint workshops in the Iberian Peninsula, Morgado \& Roncal (2009: 212-213) identified a series of quarries in the Gallumbares Valley (Loja, Andalusia), one of the most important of which was the Cerro de la Cruz, a chert location used for obtaining spark stone blanks. This location evidenced the quartering and flaking stages, with many cores, conditioning flakes and chips, and nonpreforms or finishing tools. In this region, the knapping process was carried out in the town of Loja, in the Avenida Pérez del Álamo workshop, where all the phases of flaking and knapping of the operative chain were performed (configured cores, flakes, chips, flake blanks, tools, preforms and gunflints). This type of work organization and its distribution within a territory is a common aspect in other places of exploitation, as in Brandon (Suffolk, England) (Ballin 2012; Whittaker 2001), Meusnes (Loir-et-Cher, France) (Barandiarán 1974) or in the Lessini Mountains (Verona, Italy) (Woodall \& Chelidonio 2005).

In the case of LGN, all the production stages were carried out in the quarry, as in Botorrita (Barandiarán 1974). In our case, we documented the quartering stage in the form of blocks, indeterminate pieces and some cores in an initial phase of exploitation. We also documented the flaking process, with cores in full and final phases of exploitation, flakes and blanks. The same applied to the knapping process, with the tools and gunflint preforms. It is true that given the characteristics of the site, more cores and gunflints would have been expected to be found, but this scarcity can be justified by the dimensions of the workshop (only 470 artefacts) and its local production. If we consider, for example, the production of the gunflint manufacturing workshop in Brandon in the $19^{\text {th }}$ century by a specialized craftsman, the average daily production was about 7,000-8,000 gunflints (Clarke 1935), a different order of magnitude from LGN.

The exploitation systems in LGN are mainly based on discoidal and unipolar strategies with the aim of obtaining flakes and non-bladed supports. These exploitation systems are similar to those documented in other workshops dating to the second half of the $18^{\text {th }}$ century in the Iberian Peninsula, such as Los Gallumbares (Loja), Muel, La Muela and Botorrita (all of them in Zaragoza) (Barandiarán 1974; Millán et al. 2020; Morgado \& Roncal 2009: Chapter 4; Roncal et al. 1996), which would place LGN within this chronological framework. Furthermore, the documented gunflint preforms cannot be classified within standardized 
production systems, which were implemented in France in 1775 (Lotbiniere 1984) and subsequently spread throughout Europe (Ciarlo et al. 2019). These show a peripheral and invasive retouch that sometimes obliterates the bulb, differentiating them from other tools such as threshing stones, which do not present retouch (Benito del Rey \& Benito Álvarez 1994).

However, if the exploitation does not follow standardized military patterns we assume its local purpose, according to its reduced extent, that could be related with personal gear (e.g., for hunting weapons), throughout the $19^{\text {th }}$ century and even into the early $20^{\text {th }}$ century.

In contrast to the well-organized "mine-mouth" production pattern prevalent at the gunflint factories of Brandon (England), Meusnes (France) or in the southeast of the Iberian Peninsula and some regions in the Zaragoza province, La Guinardera Quarry as a whole seems to consist of small-scale, perhaps individual activities performed by people from the area without a military purpose, but in order to supply their own firearms. This seems also to apply to Botorrita (Barandiarán 1974) and to the Lessini Mountains (Woodall \& Chelidonio 2005), where the workshops were located near farmlands and anthropic terraces (Chelidonio \&Woodall 2017).

The parameters established in this preliminary study make it possible to identify this type of workshop, but we are aware of the need to undertake further investigations and provide radiometric data for a more accurate dating, as well as traceological data to allow a better definition of these assemblages (Buscaglia et al. 2016).

\section{Conclusions}

The chert characterization of La Guinardera Quarry sheds light on other chert locations in the Sant Martí de Tous region, confirming the abundance of this raw material and the potential procurement area of chert for all those communities that have this raw material as part of their lifestyle.

The preliminary results of our study of the lithic assemblage of LGN have shown the difficulty of correctly interpreting an archaeological site. At first glance, the main attributes of the lithic assemblage suggested that we were dealing with a Middle Palaeolithic workshop according to the traditional exploitations of the area by Neanderthals groups, the abundance of flake and presence of centripetal cores (Barandiarán 1974; Gómez de Soler 2016: 94-98; Gómez de Soler et al. 2020a). However, once the material was collected and studied, the typical characteristics of a gunflint workshop emerged (e.g., bulbs marked on flakes, thick platforms in the heel, sharp edges, cores with a bulbar scar) (Pelegrin 2000). The problem was the non-appearance of gunflints themselves. Our review of the material, our identification of a set of preforms seeking standard morphologies, as well as the morphologies of the flakes (thick and quadrangular with triangular and trapezoidal sections) and the fragments of flakes (with distal transverse, or proximal or oblique fractures), suggested that this was a gunflint workshop. In addition, the presence of oxides on the ventral faces and butts of the flakes resulting from percussion with an iron hammer confirmed our hypothesis.

The presence of scarce lithic material and a manufacturing process with non-standardized reduction strategies, and the absence of historical notes on the exploitation of the area in contrast to other zones in the Catalan region as Vilaverd and Lilla (Tarragona) (Roncal et al. 1996), indicates a possible local use of this workshop for a personal supplying of gunflint for hunting weapons.

As far as its chronology is concerned, we propose that the workshop would date to no earlier than the second half of the $18^{\text {th }}$ century, given the manufacture of gunflints mainly on flakes and non-laminar blanks. In the light of the local use and its non-military purpose, the 
chronology of the workshop most probably lies between the above-mentioned date and the beginning of the $20^{\text {th }}$ century.

A more detailed and in-depth study of the site is foreseen through use-wear analyses and establishing the chronology more accurately, which would be possible if suitable materials for dating appear in future fieldwork. Archival documentation of properties and the uses of chert quarries in the region should allow us to achieve a better understanding of chert exploitation in this rich region around the town of Sant Martí de Tous (Catalan central depression, NE Iberian Peninsula).

\section{Acknowledgements}

The archaeological fieldwork was performed by Sant Martí town council and by the Departament de Cultura of the Generalitat de Catalunya project ${ }^{\circ}$ CLT009/18/00054. Funding for this research was also provided by the Catalan Government research groups $\mathrm{n}^{\circ}$ 2017 SGR 859 and 2017 SGR 836 and by the Spanish Ministry of Science, Innovation and Universities project PID2019-103987GB-C31. The research of B.G.S., G.C., MG.CH., A.S., I.R.P and J.V. is funded by the CERCA Programme/Generalitat de Catalunya. M.S.R is funded by a PTA contract (PTA2018-016561-I). A.A.B. is the beneficiary of a predoctoral research fellowship from the Gobierno de Navarra. M.S. research is funded by the UAM2019 Tomás y Valiente Program. The Institut Català de Paleoecologia Humana i Evolució Social (IPHES-CERCA) has received financial support from the Spanish Ministry of Science and Innovation through the 'María de Maeztu' program for Units of Excellence (CEX2019000945-M). We want to thank Maria D. Guillén, funded by a PEJ contract (PEJ2018-005216A), for the arrangement of some of the figures. Thanks also to Rupert Glasgow for the English revision of the manuscript.

\section{Data accessibility statement}

The authors confirm that the data supporting the findings of this study are available within the article.

\section{References}

Anadón, P., Cabrera, L., Colldeforns, B. \& Sáez, A. 1989, Los sistemas lacustres del Eoceno superior y Oligoceno del sector oriental de la Cuenca del Ebro. Acta Geológica Hispánica, 24: 205-230. (in Spanish) ("The Upper Eocene and Oligocene lacustrine systems of the eastern Ebro Basin”) URL: https://digital.csic.es/handle/10261/6830

Arbey, F. 1980, Les formes de la sílice et l'identification des evaporites dans les formations silicifiees. Bulletin des Centres de Recherches Exploration. Production Elf-Aquitaine, 4: 309-365. (in French) ("The forms of silica and the identification of evaporites in silicified formations”)

Austin, R.-J. 2020, Spanish Gunflints from Florida, USA. Gunflints beyond the British and French empires. Occasional newsletter from an informal working group. New series, 11: 3-20.

Ballin, T. 2012, "State of the art” of British gunflint research, with special focus on the early gunflint workshop at Dun Eistean, Lewis. Post-Medieval Archaeology, 46(1): 116-142. doi:10.1179/0079423612Z.0000000006 
Barandiarán, I. 1974, Un taller de piedras de fusil en el Ebro Medio. Cuadernos de Etnología y Etnografía de Navarra, 17: 189-228. (in Spanish) (“A gunflint workshop in the Middle Ebro”) URL: https://dialnet.unirioja.es/servlet/articulo?codigo=144525

Barnes A.-S. 1937, L'Industrie des pierres à fusil par la méthode anglaise et son rapport avec le coup de burin tardenoisien. Bulletin de la Société préhistorique de France, 34(7-8): 328-335. (in French) ("The gunflint industry by the English method and its relation to the tardenoisian burin stroke”) doi:10.3406/bspf.1937.4541

Benito del Rey, L. \& Benito Alvarez J.-M. 1994, La taille actuelle de la pierre à la manière préhistorique. Bulletin de la Société préhistorique française, 91(3): 214-224. (in Spanish) ("Present-day stone knapping in the prehistoric manner") doi:10.3406/bspf.1994.9770

Borja Pérez, J.-N. 1990, La llave española o de Patilla conocida como Miquelet o Miguelete. Militaria, 2: 147-150. (in Spanish) ("The Spanish key or Patilla key known as Miquelet or Miguelete”)

Borja Pérez, J.-N. 1997, Historia y el Museo de Armas. Militaria, 9: 103-119. (in Spanish) ("History and the Museum of Arms")

Buscaglia, S., Alberti, J. \& Álvarez, M. 2016, Techno-Morphological and use-wear analyses of gunflint from two Spanish colonial sites (Patagonia, Argentina). Archaeometry, 58(1): 230-245. doi:10.1111/arcm.12237

Bustillo, M.-A. 1976, Texturas de rocas silíceas inorgánicas en ambiente continental y significado genético. Estudios geológicos, 32: 371-383. (in Spanish) (“Textures of inorganic siliceous rocks in a continental environment and their genetic significance”)

Cámara, J. 2017, L’explotació de roques silícies procedents de Tous al llarg de la prehistòria. Estat de la qüestió sobre les recerques arqueològiques desenvolupades fins a l'actualitat. Miscellanea Aqualatensia, 17: 47-63. (in Catalan) ("The exploitation of siliceous rocks from Tous throughout prehistoric times. State of the art on the archaeological research carried out up to the present day")

Canals, A., Rodríguez Méndez, J., Sánchez, R., 2008, The 3COOR system for data recording in archaeology. Journal of Anthropological Sciences, 86: 133-141.

URL: http://www.isita-org.com/jass/Contents/2008\%20vol86/08_Canals.pdf

Cayeux, L. 1929, Les roches sédimentaires de France. Roches siliceuses. Imprimerie Nationale, Paris, 696 p. (in French) (“Sedimentary rocks of France. Siliceous rocks”)

Chelidonio, G. \& Woodall, J.-N. 2017, Italian firesteel flints and gunflint workshop traces. Archäologische Informationen, 40: 153-160. doi:10.11588/ai.2017.1.42478

Ciarlo, N.-C., Charlin, J., Alberti, J., Buscaglia, S., Vivar Lombarte, G., Geli Mauri, R. 2019, Size and shape analysis of gunflints from the British shipwreck Deltebre I (1813), Catalonia, Spain: A geometric morphometric comparison of unused and used artefacts. Archaeological and Anthropological Sciences, 11: 6569-6582. doi:10.1007/s12520-01900925-1

Clarke, R. 1935, The Flint-Knapping Industry at Brandon. Antiquity, 9(33): 38-56. doi:10.1017/S0003598X00009959 
Clop, X., Faura, J.-M., Piqué, R. \& Gibaja, J.-F. 2005, Els Vilars de Tous (Igualada, Barcelona): una estructura de habitación y producción lítica del V milenio cal BC. In: Actas del III Congreso del Neolítico en la Península Ibérica (Roberto Ontañón, R, García-Moncó, C. \& Arias, P., Eds.). Universidad de Cantabria. Servicio de Publicaciones, Santander: p. 551-558. (in Spanish) ("Els Vilars de Tous (Igualada, Barcelona): a dwelling and lithic production structure from the 5th millennium BC”)

Colldefons, B., Anadón, P. \& Cabrera, L. 1994, Litoestratigrafía del Eoceno superiorOligoceno Inferior de la zona oriental de la Cuenca del Ebro. Sector de Igualada-Santa Coloma de Queralt. Geogaceta, 16: 98-101. (in Spanish) (“Upper Eocene-Lower Oligocene lithostratigraphy of the eastern Ebro Basin. Igualada-Santa Coloma de Queralt sector") URL: http://hdl.handle.net/10261/144462

Emy, J. 1978, L'Histoire de la Pierre à fusil. Société d'exploitation de l'imprimerie d'Alleaume, Blois, 380 p. (in French) ("The History of gunflint. Company operating the Alleaume printing works”) URL: http://hdl.handle.net/10261/144462

Enrich, J. 1981, Estació-Taller de sílex a Sant Pere de l’Erm (Sant Martí de Tous, Anoia). In: Tous, Mil anys d'Història (Ajuntament de Sant Martí de Tous, Ed.), Publicacions de l'Abadia de Montserrat, Barcelona: p. 9-22. (in Catalan) (“Sant Pere de l'Erm Flint Workshop-Station (Sant Martí de Tous, Anoia)”)

Fowler, M.-J.-F. 1992, A gun-flint industry at Martins Clump, Over Wallop, Hampshire. Proceedings of the Hampshire Field Club Archaeological Society, 48: 135-142.

Gómez de Soler, B. 2016, Procedencia del aprovisionamiento lítico durante el Paleolítico medio en el yacimiento del Abric Romaní (Capellades, España). Niveles M, Oa y P. Ph.D. Thesis at the Department of History and Art History, Universitat Rovira i Virgili, Tarragona, 387 p. (in Spanish) ("Provenance of the lithic supply during the Middle Palaeolithic at the Abric Romaní site (Capellades, Spain). Levels M, Oa and P”)

Gómez de Soler, B., Chacón, M.-G., Bargalló, A., Romagnoli, F., Soto, M., Vallverdú, J. \& Vaquero, M. 2019, Mobilité territoriale pendant le Paléolithique moyen en contextes Discoïdes et Levallois. Exemple du site de l’Abric Romaní (Barcelone, Espagne): niveau $\mathrm{M}$ et sous-niveau Oa. In: La conquête de la montagne: des premières occupations humaines à l'anthropisation du milieu. Proceedings of the $142^{a}$ Congrès National des Sociétés Historiques et Scientifiques (Deschamps, M., Costamagno, S., Milcent, P.-Y., Pétillon, J.-M., Renard C. \& Valdeyron, N., Eds.), Éditions du Comité des travaux historiques et scientifique, Paris: p. 1-29. (in French) ("Territorial mobility during the Middle Palaeolithic in Discoid and Levallois contexts. Example of the Abric Romaní site (Barcelona, Spain): level M and sub-level Oa”) doi:10.4000/books.cths.6212.

Gómez de Soler, B., Soto, M., Vallverdú, J., Vaquero, M., Bargalló, A., Chacón, M.-G., Romagnoli, F. \& Carbonell, E. 2020a, Neanderthal lithic procurement and mobility patterns through a multi-level study in the Abric Romaní site (Capellades, Spain). Quaternary Science Reviews, 237: 106315. doi:10.1016/j.quascirev.2020.106315

Gómez de Soler, B., Soto, M., Vallverdú, J.1,2, Bargalló A., Chacón, M. G., Romagnoli, F., Vaquero, M. 2020b, The Panadella chert (Montmaneu Formation): A high-quality raw material in the Abric Romaní sequence (NE Iberian Peninsula). Archaeological and Anthropological Sciences, 12: 252. doi:10.1007/s12520-020-01198-9 
Laplace, G. 1972, La typologie analytique et structurale: Base rationnelle d'étude des industries lithiques et osseuses. Banques de données archéologiques. Colloques nationaux du CNRS, 932: 91-143. (in French) (“Analytical and structural typology: A rational basis for the study of lithic and bone industries")

Laplace, G. \& Méroc, L. 1954, Application des coordonées cartésiennes à la fuille d'un gisement. Bulletin de la Société Préhistorique Française, 51(1-2): 56-66. (in French) ("Application of Cartesian coordinates to the excavation of a site") doi:10.3406/bspf.1954.12427

Lotbeniere, Seymour de. 1984, Gunflint recognition. International Journal of Nautical Archaeology, 13: 206-209. doi:10.1111/j.1095-9270.1984.tb01191.x

Sáez, A. 1987, Estratigrafía y sedimentología de las formaciones lacustres del tránsito Eoceno-oligoceno del NE de la Cuenca del Ebro. PhD Thesis at the Department of Geochemistry, Petrology and Geological Prospecting, Universitat de Barcelona, Barcelona, 352 p. (in Spanish) ("Stratigraphy and sedimentology of the lacustrine formations of the Eocene-Oligocene transit of the NE Ebro Basin”)

Merino, J.-M. 1965, Las piedras de fusil ante el arqueólogo. Munibe 17: 117-119. (in Spanish) ("Gunflints in front of the archaeologist")

URL: http://www.aranzadi.eus/fileadmin/docs/Munibe/1965117119.pdf

Morgado, A. \& Roncal, E. 2009, Los últimos talladores de sílex. Fundación Ibn al-Jatib de Estudios de Cooperación Cultural, Granada, 342 p. (in Spanish) ("The last flintknappers")

Munsell Color 2013. Munsell Rock Color Book. Geological Society of America (GSA), Grand Rapids (Michigan), 19 p.

Ortí, F., Rosell, L., Inglès, M. \& Playà, E. 2007, Depositional models of lacustrine evaporites in the SE margino of the Ebro Basin (Paleogene, NE Spain). Geologica Acta, 5(1): 1934. doi:10.1344/105.000000307

Palomo, A. \& Gibaja, J.F. 2006, Pervivencias del uso del sílex en época moderna y contemporánea. Revista de Arqueología del siglo, 21: 297: 34-41. (in Spanish) ("The persistence of the use of flint in the modern and contemporary period")

Pelegrin, J. 2000, Les techniques de débitage laminaire au Tardiglaciaire: critères de diagnose et quelques réflexions. In: L'Europe Centrale et Septentrionale au Tardiglaciaire. Mémoire du Musée de Préhistoire d'Ille de France, 7 (Valentin, B.; Bodu, P. \& Christensen, M. Nemours, Eds.), Éditeur APRAIF (Association pour la promotion de la recherche archéologique en Ile-de-France), Nemours: p. 73-86. (in French) (“Laminar knapping techniques in the Tardiglacial period: criteria for diagnosis and some thoughts”)

Peón, A. \& Alonso, F. 1975, Serie Magna, E. 1:50.000, Igualada (Hoja n³91). Instituto Geológico Minero de España, Madrid. (in Spanish) (“Geological Map of Spain. E. 1:50.000. Sheet n'391 (Igualada)”)

Picazo Millán, J.V., Morgado-Rodríguez, A., Fanlo Loras, J., Pérez-Lambán, F. 2020, El aprovechamiento histórico del sílex para piedras de fusil. El caso del río Huerva (Zaragoza). Zephyrus, 86: 191-216. (in Spanish) ("The historical use of flint for gunflints. The case of the river Huerva (Zaragoza)”) doi:10.14201/zephyrus202086191216 
Rodríguez Hernández, A.-J. 2016, ¿Evolución o innovación? Los cambios técnico-tácticos en el armamento del ejército español durante el relevo dinástico: nuevas consideraciones. Cuadernos de Historia Moderna, 41(2): 273-294. (in Spanish) (Evolution or Innovation? The Technical and Tactical Changes in the Armament of the Spanish Army During the Dynastic Change: New Considerations) doi:10.5209/CHMO.53812

Roncal, E., Morgado, A. \& Martínez, G. 1996. Las piedras de chispa: Una producción lítica olvidada en España. Munibe, 48: 105-123. (in Spanish) Sparkstones: A forgotten lithic production in Spain”)

URL: http://www.aranzadi.eus/fileadmin/docs/Munibe/1996105123AA.pdf

Roncal, E. \& Morgado, A. 1999, El proceso de producción de soportes para piedras de chispa de “Cuarto Real de Santo Domingo (Granada)”. Mainake, 17-18(1995-96): 277-306. (in Spanish) ("The production process of spark stone supports from "Cuarto Real de Santo Domingo (Granada)”) URL: https://www.cedma.es/catalogo/mainake.php?ref=13010

Sánchez de la Torre, M., García-Simón, L.-M., Domingo R., Montes, L., Mangado, X. 2016, The chert workshop of Tozal de la Mesa (Alins del Monte, Huesca, Spain) and its exploitation in historical times. Journal of Lithic Studies, 3(2): 661-670. doi:10.2218/jls.v3i2.1859

Schavelzón, D. 2013, Lítica histórica. La piedra en Buenos Aires en los siglos XVI al XX. Usos y tecnologías. Aspha Ediciones, Buenos Aires, 109 p. (in Spanish) ("Historical lithics. Stone in Buenos Aires from the 16th to the 20th centuries. Uses and technologies”) URL: www.iaa.fadu.uba.ar/cau/ebooks/Litica_historica.pdf

Solinas, G. 1971, Selci lavorate per acciarino nell'Italia settentrionale e in Francia. Studi Trentini di Scienze Naturali, 48(2): 326-343. (in Italian) ("Worked flints for tinder in northern Italy and France”)

Sopena Garreta, J. 1978, Historia del armamento español. Tomo I. Las armas de fuego (17001867). Ed. JSG, Barcelona, 299 p. (in Spanish) (History of Spanish armaments. Volume I. Firearms (1700-1867))

Stevenson, C.-M., Bikowski, E., Neff, H., Orliac, M. 2007, Investigations into the European provenance of historic gunflints from fort Christanna, Virginia, through trace element chemistry. Archaeology of Eastern North America, 35: 49-62.

White, S. W. 1975, On the origins of gunspalls. Historical Archaeology, 9(1): 65-73. doi:10.1007/bf03373431

Whittaker, J. 2001. The oldest British industry: Continuity and obsolescence in a flintknapper's sample set. Antiquity, 75: 382-390. doi:10.1017/S0003598X00061032

Woodall, J.-N. \& Chelidonio, G. 2006. Gunflint workshop traces in the Lessini Mountanis (Verona, Italy). Flintknappers and smugglers at the end of the Venetian Republic. Stone Age - Mining Age - Der Anschnitt, Beiheft, 19: 1-14. 